\title{
The Artist Libraries Project in the Labex Les passés dans le présent
}

\author{
Félicie Faizand de Maupeou ${ }^{1}$ \\ ${ }^{1}$ Université Paris Nanterre, France - feliciedemaupeou@gmail.com \\ Corresponding author: Ségolène Le Men, Emerita Professor in Art History, HAR, \\ UPL, Univ Paris Nanterre, F92000 Nanterre France segolene.lemen@gmail.com
}

\begin{abstract}
The creation of the Artist Libraries Project was sparked by the observation that artist libraries are still not well known, yet many art historians are interested in this archive for the value it adds to understanding the person behind the artist and his or her creative process. The problem is that these libraries are rarely physically preserved. To remedy this dispersion, we built an online database and a website www.lesbibliothequesdartistes.org that house this valuable source in the form of lists of books and their electronic versions. First data on Monet's library have been made available, and several additional artist libraries from the $19^{\text {th }}$ and $20^{\text {th }}$ centuries are on the way for 2019 . By gathering all these bibliographical data in a central database, it's possible to explore one library and to compare several.

This article explains how we built the database and the website and how the implementation of those IT tools has raised questions about the use of this resource as an archive on the one hand, as well as its value for art history on the other.
\end{abstract}

\section{keywords}

history of art; library; database; CMS; Omeka

\section{CONTEXT}

The Artist Libraries Project ${ }^{1}$ has been initiated by Ségolène Le Men within a larger project about 'dialectical images, imaginary museums, and virtual museums' which was selected in 2014 by the labex Les Passés dans le présent at Université Paris Nanterre (research team HAR histoire des arts et des représentations). The author has been in charge of its development since 2016. The project started with a challenging case study, asserting that Monet's library offered a source which showed that his art went beyond optical issues ${ }^{2}$. Following the famous sentence of Cezanne, Monet ce n'est qu'un xil mais bon dieu quel xil!

\footnotetext{
${ }^{1}$ The project is conducted in the framework of the Labex Pasts in the Present and has therefore benefited from the state aid managed by the ANR under the Investissements d'avenir program with the reference ANR-11LABX-0026-01. It is also funded by the Paris Lumière University. A scientific committee and a project committee meet regularly.

${ }^{2}$ About the issues involved in the study of Monet's library, see Ségolène Le Men. «Les livres de Giverny », La bibliothèque de Monet, Citadelles \& Mazenod, 2013, p. 4-14 and 234-235. Her interest in the topic started with a discussion about art and literature in her Monet monograph, Monet, Abbeville Press, 2010 (Citadelles \& Mazenod, 2010 and 2017).
} 
the historiography of impressionism built the idea that the members of this movement were almost completely disconnected from their context and their time. Even if the thinking on this has evolved lately, many studies still ignore Monet's inspirations beyond just nature, and instead focus narrowly on his concern with painting, color and pattern, as if he was divorced from time. Monet himself promoted this image by claiming in particular to abhor theory. $\mathrm{He}$ affirmed that everyone has his own calling; his was to paint, not to comment on his painting. It is indeed true that Monet never wrote a theoretical text and that he was always reluctant to analyze his own works and his technique. As early as 1895, he categorically declared: "[...] I hate being put on stage ... it is already plenty enough to give to the public what one makes without smothering them with what one thinks" ${ }^{3}$. In the same vein, he answers to Louis Vauxcelles, in 1900, about a questionnaire on the technique of painters to be published in $L e$ Figaro: "I understand very well the interest this can have for you, I recognize this and will be the first to read responses that will be addressed to you. But as for me, I will stick with my brushes ${ }^{4}$ ". He maintains his point of view until the end of his life; a few months before he dies, in March 1926, he wrote: "[...] I've always hated theories, [...] all I have the merit to have done is paint directly in front of nature, seeking to give my impression before the most fugitive effects, and I remain regretful to have been at the origin of the name of a group, most of whom had nothing of an impressionist about them ${ }^{5}$ ".

Nevertheless, it is difficult to embrace the argument that Monet was divorced from time and thought when we consider the intellectual, social, political and scientific context in which he lived in the late $19^{\text {th }}$ century and turn of the $20^{\text {th }}$ century. It is even less credible when we consider how revolutionary the impressionist movement was in the history of landscape painting. Some studies concerning the subjects of his paintings have already questioned this approach demontrating, for example, the symbolic significance of the choice of serial motives ${ }^{6}$ such as haystacks ${ }^{7}$ or Rouen Cathedral ${ }^{8}$. The presence of literary men and politicians in his entourage suggests also that Monet was in fact strongly anchored in his time. This perspective will be confirmed by studying his library, which can be peer as a source to understand the man behind the painter. There is origin of the Artist Libraries Project.

Monet's library has been conserved in the second studio of the painter. This building now houses the administrative offices of the Monet Foundation and is therefore not included in the public tour. An initial study on his library led to a book [Le Men et all, 2013]. This book is an anthology of texts taken from the books of the library, together with illustrations, either taken from these books, or from Monet's or his friends' work. This book also includes a bibliography of titles in the artist's library, some of which contain author dedication pages. This aroused interest among researchers and compelled us to expand our work to all artists' libraries. The problem is that those libraries are rarely physically preserved. Therefore, they

\footnotetext{
3 “ j'ai horreur d'être mis en scène... c'est déjà bien assez de livrer au public ce que l'on fait sans l'assommer de ce que l'on pense", Letter W 1308 to an unknown address, Giverny, June 26, 1895. W refers to Daniel Wildenstein's Monet: catalogue raisonné, [1974]., Köln-Lausanne, Taschen -Wildenstein Institute, 1996,5 vol.

4 “Je comprends très bien l'intérêt que cela peut avoir pour vous, je le reconnais et serai le premier à lire des réponses qui vous seront adressées. Mais pour moi, je m'en tiens à mes pinceaux”, Letter W1570 To Louis Vauxcelles, Giverny, September 28, 1900.

5 “ j'ai toujours eu horreur des théories, enfin que je n'ai que le mérite d'avoir peint directement devant la nature en cherchant à rendre mes impressions devant les effets les plus fugitifs, et je reste désolé d'avoir été la cause du nom donné à un groupe dont la plupart n'avait rien d'impressionniste...”, Letter W2626 to E. Charteris, Giverny, June 21, 1926.

${ }^{6}$ Monet in the 90s. The Series Paintings. exhibition catalogue, Museum of Fine Arts, Boston (by Paul Hayes Tucker), The Art Institute of Chicago, and the Royal Academy of Arts, London, February-December 1990.

${ }^{7}$ Monet's Years at Giverny : Beyond Impressionism [exhibition catalogue, Metropolitan museum of art, 1977].

${ }^{8}$ Bénédicte TRÉMOLIÈRES, Éléments pour une histoire matérielle de l'impressionnisme: les Cathédrales de Claude MONET, Rouen Normandie, Rouen, 2016.
} 
require a great deal of investigation, which means reconstitution and cross-referencing of several sources, such as correspondence, workbooks or testimony of his close relatives. Such research is mostly conducted individually by researchers who adopt a monographic approach: a researcher interested in an artist finds his library and decides to study it as a new source to learn more about his personality or his work. Those lists of books are thus disseminated in monographic studies, published or unpublished academic works, articles, inventories of libraries... One of the major challenges of this project is to remedy this dispersion. To achieve this, digital technology, i.e. the creation of an online database, has appeared the best option, for several reasons. It makes it possible to handle large amounts of data, to cross-search by artist, work, author..., to enrich data thanks to interoperability and to browse digital versions. Several institutions keep artists' libraries but they are not distinguished as a separate fund. That's why the reader can not easily identify and find them. By putting online not only a cartography of these libraries but also the inventory of the works they contain, this digital project gives an unprecedented access to an essential source of art history. Since 2015, the project is led at Paris Nanterre University by the Labex Pasts in the Present and the research team History of arts and representations, and conducted under the direction of Ségolène Le Men. The website www.lesbibliothequesdartistes.org was launched in Jan 2018 to house lists of works and electronic versions of works. First data on Monet's library were made available, and several additional artist libraries from the $19^{\text {th }}$ and $20^{\text {th }}$ centuries are on the way for 2019. By gathering all these bibliographical data in a central database, it's possible to explore one library and to compare several.

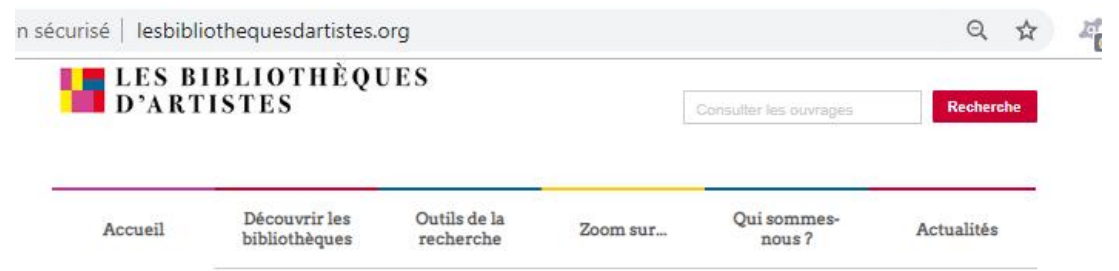

\section{Entrez dans les bibliothèques d'artistes}

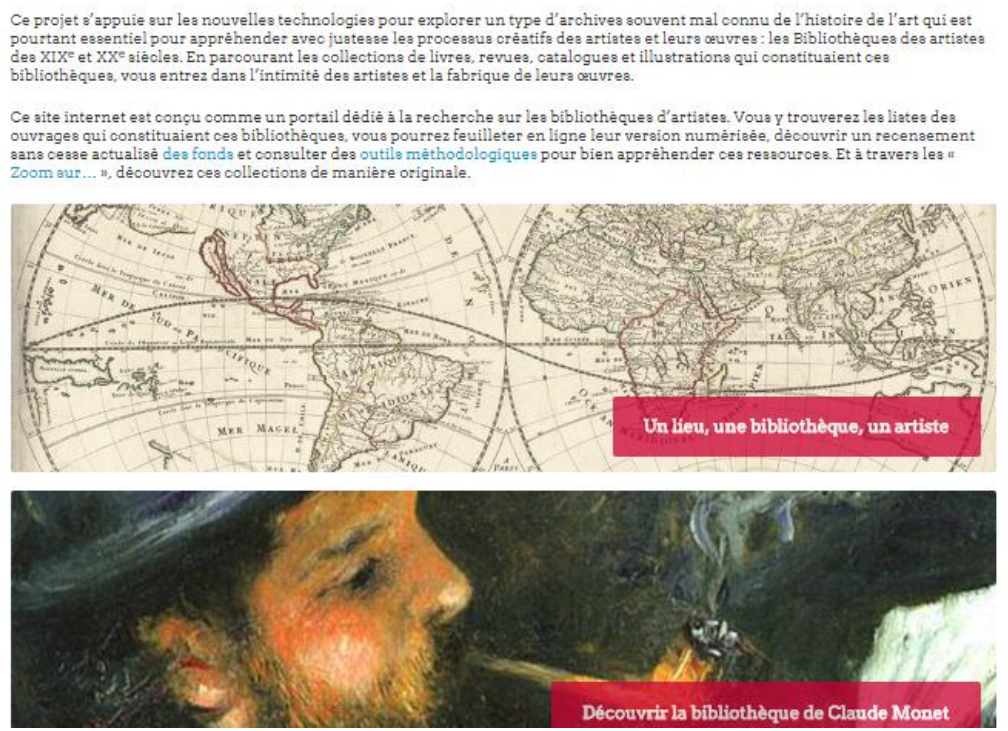

Figure 1. Home page of www.lesbibliothequesdartistes.org 


\section{THE ARTIST'S LIBRARY: AN IMPORTANT AND YET UNKNOWN RESOURCE $^{9}$}

To art historians, the library of an artist is an extremely meaningful source. The list of books, authors, dates of publications, dedication pages, annotations, classification adopted and other traces of reading... provide clues to discover a little further the intimacy of an artist. Which authors did Monet read? Which authors sent him their books with a dedication page? What types of literature did he prefer? How did he treat his books? Did he take care of them or, on the contrary, did he mistreat them? Did he annotate them? Did he dog-ear the pages? By answering these questions and a close examination of the books, it is possible to map Monet's mental universe, to outline his cultural horizon, to draw a part of his social network and to discover a part of its musée imaginaire ${ }^{10}$. Even though a work of art is never a literal transcription of a text, even though the links between what an artist has seen and the work he creates are far from obvious, his books and the illustrations they contain undoubtedly constitute an inspiration. By studying his library, the aim is to learn more about the man and the artist in order to better understand his creative process and his works. As [Levaillant et all, 2010] explain: "A book source makes it possible to identify, date and explain a theme or a motif, according to the current iconographic method that crosses textual indications and visual comparisons. It also makes it possible to demonstrate an intellectual or technical "filiation" and to inscribe a particular work in a socio-cultural environment by following an iconological method stamped with the seal of Panofskyan scholarship, not to mention that books are often reserves of images of all kinds; among them, in particular, albums read or viewed in childhood and adolescence, of which two or three titles are sufficient to restore an imaginary in act in the artistic process ${ }^{11}$ ". According to this definition, libraries are new evidences that art historians can add to the genetic file of an artwork.

\section{CHALLENGES OF DIGITAL LIBRARY PROCESSING}

Whether genetic, iconographic or textual, whether monographic or global and contextual, there are many approaches to studying artists' libraries. Digital humanities are another way to enlighten the richness of this resource. The Artist Libraries Project is also characterized by interdisciplinarity, as it compels art historians, literary historians and curators working together to make accessible to researchers and the general public not only the lists of the publications in artists' libraries from the $19^{\text {th }}$ and $20^{\text {th }}$ centuries but also their digital version. The goal of the Artist Libraries Project is to build a database that contains the bibliographical information of each book - i.e. editing, illustrations, annotations, dedication pages, placement on the shelf.... The search functionality will allow to search one artist's library or to compare

\footnotetext{
9 Ségolène Le Men, 'Artists Libraries: A Resource for Art History, Perspective, 2016-2, p.111-132. https://journals.openedition.org/perspective/6872

${ }^{10}$ See the section 'Une voie d'accès au dossier génétique et au musée imaginaire des artistes", ibid. Among other examples, the painter Millet has been dicussed in Chantal Georgel, Millet, Citadelles \& Mazenod, 2014

11 «Une source livresque permet d'identifier, de dater et d'expliciter un thème ou un motif, selon la méthode iconographique courante qui croise les indications textuelles et les comparaisons visuelles. Elle permet aussi de démontrer une «filiation», intellectuelle ou technique, et d'inscrire enfin telle ou telle œuvre dans un environnement socio-culturel en suivant une méthode iconologique frappée au sceau de l'érudition panofskyenne sans compter que les livres sont souvent des réserves d'images en tout genre ; parmi eux, notamment, les albums lus ou regardés dans l'enfance et l'adolescence, dont deux ou trois titres suffisent à restituer un imaginaire en acte dans le processus artistique », Françoise LEVAILlant, Jean-Roch BouILLER et Dario GAMBONI (dirs.), Introduction, Les bibliothèques d'artistes : XXe-XXIe siècles, Paris, PUPS, 2010, p. 12.
} 
several. Today limited to Monet's library ${ }^{12}$, this project aims to ultimately bring together many of these libraries in order to establish international and intergenerational comparisons between the musée imaginaire, understood in its broadest sense, of very different artists. Furthermore, by gathering the sources in one digital tool, the project the Artist Libraries Project opens new perspectives on the circulation of ideas, concepts, poetics and images in the art world, on their involvement in the elaboration process and the constitution of networks and groups. For example, the significance of a book for a specific artistic group or its transmission from one generation to another is measurable. As they are a channel to spread ideas and concepts, artists' book collections sketch the cultural landscape of an era and a place. In the end, a history of ideas emerges. They also make it possible to verify certain hypotheses, such as the diffusion of scientific theories on color and light in the $19^{\text {th }}$ century. Did the Impressionists read Goethe, Chevreul or Helmholtz? Or did they have access to these theories through second-hand literature or journals? Or, on the contrary, are these publications completely absent from their shelves? Monet didn't have a lot of spezialized books. He only owned Félix Bracquemond's treatise ${ }^{13}$. Conversely he possessed a lot of more general-interest books by author, now forgotten, who nevertheless played a key role in the diffusion of these artistic theories to the general public ${ }^{14}$. Journals played the same role. Monet subscribed to $L a$ Revue Blanche. Volumes 5 to 26 are kept in the library. Beyond this artistic example, thanks to Monet's library, we enlighted his interest in the politics of his time, especially the first World War and the Dreyfus affair. Even more surprising is the colonial issue which emerges in several books. Most of them draw a negative picture which is conformed to Monet's political sensitivity. Illustrations in these books are another field of interest in this source because they reveal the musée imaginaire, in the proper sense this time. For example beyond the motif, the scenography of the Waterlilies is also inspired by Japan. Monet never went there but he could know these layouts through the books and in particular the sales catalog of Hayashi's collection in Paris in $1902^{15}$. Often considered as art books due to their rich illustrations, exhibition or sales catalogs, which are very often kept in artists' libraries, are another example of the richness of libraries as a source ${ }^{16}$. Their mere presence, and sometimes the annotations of price or handwritten notes they contain, reveals the sensibility of an artist. In the sales catalog of Degas's collection in $1918^{17}$, Monet had written the auction price of a painting by El Greco and Delacroix, thus leaving a hint of his artistic tastes.

Publishing artists' libraries online satisfies above all a need for accessibility. Lists of books are thus no longer limited to the print edition but are accessible to everyone and everywhere. Database techniques facilitate search queries and comparison. Thanks to the database technology, we the analyses move from the monographic approach to the comparative one. According to Le dictionnaire de l'École nationale supérieure des sciences de l'information et des bibliothèques, "Digital libraries offer real digital collections, according to a defined documentary policy. They are supplied either by digitization operations (heritage documents

\footnotetext{
12 Félicie Faizand de Maupeou, «Les bibliothèques d'artistes au prisme des humanités numériques: la bibliothèque de Monet», Perspective: actualité en histoire de l'art, 2, 2016, p.175-181. https://journals.openedition.org/perspective/6939

${ }^{13}$ Félix Bracquemond, Du dessin et de la couleur, Paris, G. Charpentier, 1885.

${ }^{14}$ On this issue, see Félicie de Maupeou, «Toiles et croquis de Claude Monet à l'âge d'or du reflet », La Lumière parle. Lumières, reflets, miroirs : du Moyen-âge à l'art vidéo, Rouen, PURH, p.169-184.

${ }^{15}$ Catalogue de vente, objets d'art du Japon et de la Chine, peintures, livres, collection Hayashi, Paris, 27 janvier-2 février 1902, Hôtel Drouot.

${ }^{16}$ The research project Artl@s studies exhibition catalogues by putting online a global database linked to mapping and analysis tools.

${ }^{17}$ Catalogue des tableaux modernes et anciens - aquarelles, pastels, dessins par [...] composant la collection de Edgar Degas, Paris, galerie Georges Petit, vente des 26-27 mars 1918.
} 
or not) or by natively digital documents. The contents are organized to facilitate consultation $^{18,}$. While it partly reflects the objectives of a traditional library, this definition also suggests the many and varied possibilities offered by this new tool, including extensive consultation functionalities. A digital library is therefore not just a copy of a physical library; it is a continuation of it and even more a real extension. This statement is in line with the reflections espoused for several years by the philosopher Pierre Lévy, for whom the virtual is what exists in power and not in action. It means that the virtual world is not opposed to reality but to the present: "Virtualization is not a derealization (the transformation of a reality into a set of possibilities), but a change of identity, a shift in the ontological centre of gravity of the object under consideration: instead of being defined mainly by its topicality (a "solution"), the entity now finds its essential consistency in a problem field. Virtualizing any entity consists of discovering a general question to which it relates, mutating the entity towards that question and redefining the initial topicality as an answer to a particular question ${ }^{19}$ " Despite his enthusiasm for digital technology, the sociologist Michel Wieviorka has reservations about virtualization of thought and warns against the risk of "theoretical impoverishment in front of an overly quantitative approach to historical, sociological, anthropological questions ${ }^{20 "}$. In addition to this theoretical uncertainty, the use of digital technology poses the challenge of practical implementation. Researchers in the humanities and social sciences have to deal with technologies that they often do not master and with project logic that is quite different from traditional research practices. We will examine a number of these questions through the example of implementing the Artist Libraries Project.

\section{IDENTIFYING THE TOOLS}

One of the contributions of the digital humanities is the strengthening of the link between the tool and its use. Indeed, the search for suitable digital tools requires in-depth reflection on the objective of a given study. Moreover, building the database architecture involves questioning the nature of its corpus, its characteristics and its limits. An effort to define these elements must be the first step of such a project. What kind of documents are we processing? Transcribed texts, digitized texts, photographies, maps, plans, video material, audio material... Where do they come from? Who will consult them? Is the database likely to evolve or is it static? Should the database be interoperable? Is there an indexing vocabulary to describe our data? Is it a homogeneous or heterogeneous corpus? etc. In our case, the corpus is simultaneously open and close. Open because we don't know yet all the libraries we will integrate into the database but close because it will always be bibliographical data: on the one

\footnotetext{
18 «Les bibliothèques numériques proposent de véritables collections numériques, selon une politique documentaire déterminée. Elles sont alimentées soit par des opérations de numérisation (documents patrimoniaux ou non), soit par des documents nativement numériques. Les contenus sont organisés pour en faciliter la consultation », http://www.enssib.fr/le-dictionnaire/bibliotheques-numeriques (consulted on the 01/21/2019).

19 «La virtualisation n'est pas une déréalisation (la transformation d'une réalité en un ensemble de possibles), mais une mutation d'identité, un déplacement du centre de gravité ontologique de l'objet considéré : au lieu de se définir principalement par son actualité (une « solution »), l'entité trouve désormais sa consistance essentielle dans un champ problématique. Virtualiser une entité quelconque consiste à découvrir une question générale à laquelle elle se rapporte, à faire muter l'entité en direction de cette interrogation et à redéfinir l'actualité de départ comme une réponse à une question particulière. », Pierre Lévy, Qu'est-ce que le virtuel ?, Paris, 1995, p. 15.

20 «appauvrissement théorique face à une approche exagérément quantitative de questions historiques, sociologiques, anthropologiques », Philippe Testard-Vaillant, «Interview de Michel Wieviorka : les sciences humaines et sociales à l'ère numérique », in CNRS Le journal, published online on January 10, 2014: https://lejournal.cnrs.fr/articles/interview-de-michel-wieviorka-les-sciences-humaines-et-sociales-a-lerenumerique (consulted on the 01/21/2019).
} 
hand, bibliographic records of the books of each artist's library, which mentions the transcription of handwritten dedications and all characteristics of a copy and, on the other hand, the bibliographical description of the digitized version of the books. Built on Monet's case, the digital tool as part of the Artist Libraries Project has to be reliable enough to support a large number of libraries but also flexible enough to adapt to the specificities of each. Our database is built on qualified Dublin Core vocabulary ${ }^{21}$, a descriptive format that initially included fifteen fields to describe any type of document. Created in 1995, the Dublin Core has now been extended to fifty-five descriptive fields. The use of this standard makes the system interoperable, i.e. the bibliographic records we create can be retrieved by other systems and conversely, records created by other libraries can be retrieved. We also use RAMEAU indexation language ${ }^{22}$ to describe the books. To give access to digital books, we choose not to scan or host the books stored in the libraries because they are often common books which are already digitalized by numerous projects such as www.gallica.bnf.fr or www.openlibrary.org. Moreover, systematic digitalization as part of an academic project is often too expensive. We recovered the digital books mostly via exportable readers. On the contrary, we will photograph the marks that individualize the copy (handwritten dedication, notes, erasures, bookmarks...) and make them accessible on the website.

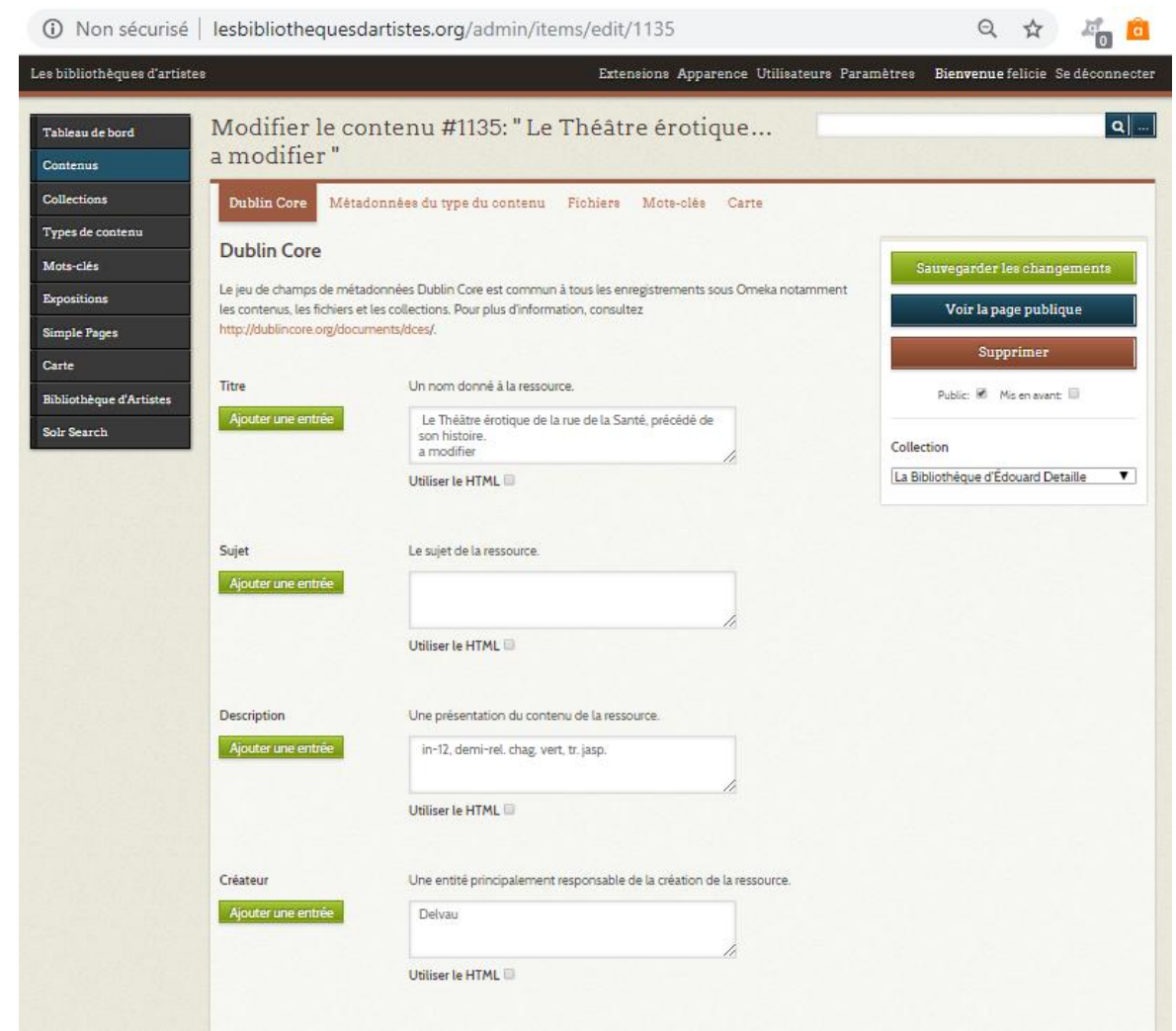

Figure 2. Dublin Core form to add a new book on the database

The origin and the type of collections may also raise copyright issues and influence the level of security that must be applied to them. For example, heritage documents need a specific

\footnotetext{
${ }^{21}$ http://www.dublincore.org/

${ }^{22}$ RAMEAU (Répertoire d'autorité-matière encyclopédique et alphabétique unifié) is the language of indexation material used, in France, by the National Library of France, the university libraries, many libraries of public reading or research as well as several private organizations. It has been independently developed since 1980, in relation to the "Subject Heading Directory" of Laval University in Quebec, and with the list of Subject Headings of the Library of Congress (Library of Congress Subject Headings)." http://rameau.bnf.fr/informations/rameauenbref.htm.
} 
protection from being downloaded. In our project, the bibliographical data are not sensitive but the photographs of handwritten marks can be if the copyright is still in force. That's why they will be protected from being downloaded. The type of the original document may also affect the important issue of storage. Files of transcribed text are not very big and therefore do not require very much storage space. Conversely, images, especially in high quality - which is always desirable so that the user can "zoom in" - take up a great deal of space. It is consequently necessary to find a web host that has storage and flow management capacities adapted to the project. The web host must also provide an appropriate dissemination platform. In France, the number of academic projects with a digital component has grown quickly in recent years, but no designated institution for hosting them existed until 2013. Since then, Very Large Research Infrastructure ("Très Grande Infrastructure de Recherche", TGIR) Huma-Num aims to meet this expectation. According to the Huma-Num website, "HumaNum aims at supporting research communities by providing services, assessment and tools on digital research data. Huma-Num coordinates the production of digital data while offering a variety of platforms and tools for the processing, conservation, dissemination and long-term preservation of digital research data ${ }^{23}$. . Organized in consortia, it is intended to ensure not only the technical follow-up of projects but also to offer spaces for exchange and mutual assistance around common themes and objects. The Artist Libraries Project has been using TGIR services since the latter signed an agreement in 2016 with the labex Les Passés dans le present.

Once these prerequisites were established and the criteria defined, we then needed to choose an appropriate data management system. The real interdependence between IT tools and the object under examination appears once more during this phase. We required a system that could not only store and manage bibliographical data but also compare them and distinguish content specific to a book, such as the illustrations it contains. This corresponds to a flat format, unlike archive management, which requires a hierarchical format, since it deals with boxes, containing files that themselves contain documents. Numerous software programs are available to manage digital libraries. Many require payment while some are free. After a long search for the most suitable management tool for the Artist Libraries Project, the choice was made to use the free software Omeka, developed by the Roy Rosenzweig Center for History and New Media at George Mason University (Fairfax, VA), which meets many of our criteria $^{24}$. Omeka is a Content Management System (CMS), a web publishing platform which manages digital content - in our case bibliographic records, linked to the digitized version of books. These data are organized by collections - each a different library - and we can consult them by list or via a search engine. While it performs the two functions, data management and dissemination remain well separated. The design or the different features can evolve or even change completely, and the content is not compromised. Omeka also has the advantage of being built on Dublin Core vocabulary. In addition to being free, open-source software benefits from a large community of users who run blogs, post tutorials online and respond via forums to technical problems that may arise.

\footnotetext{
${ }^{23}$ https://www.huma-num.fr/about-us (consulted on 01/31/2019).

${ }^{24}$ https://omeka.org/
} 


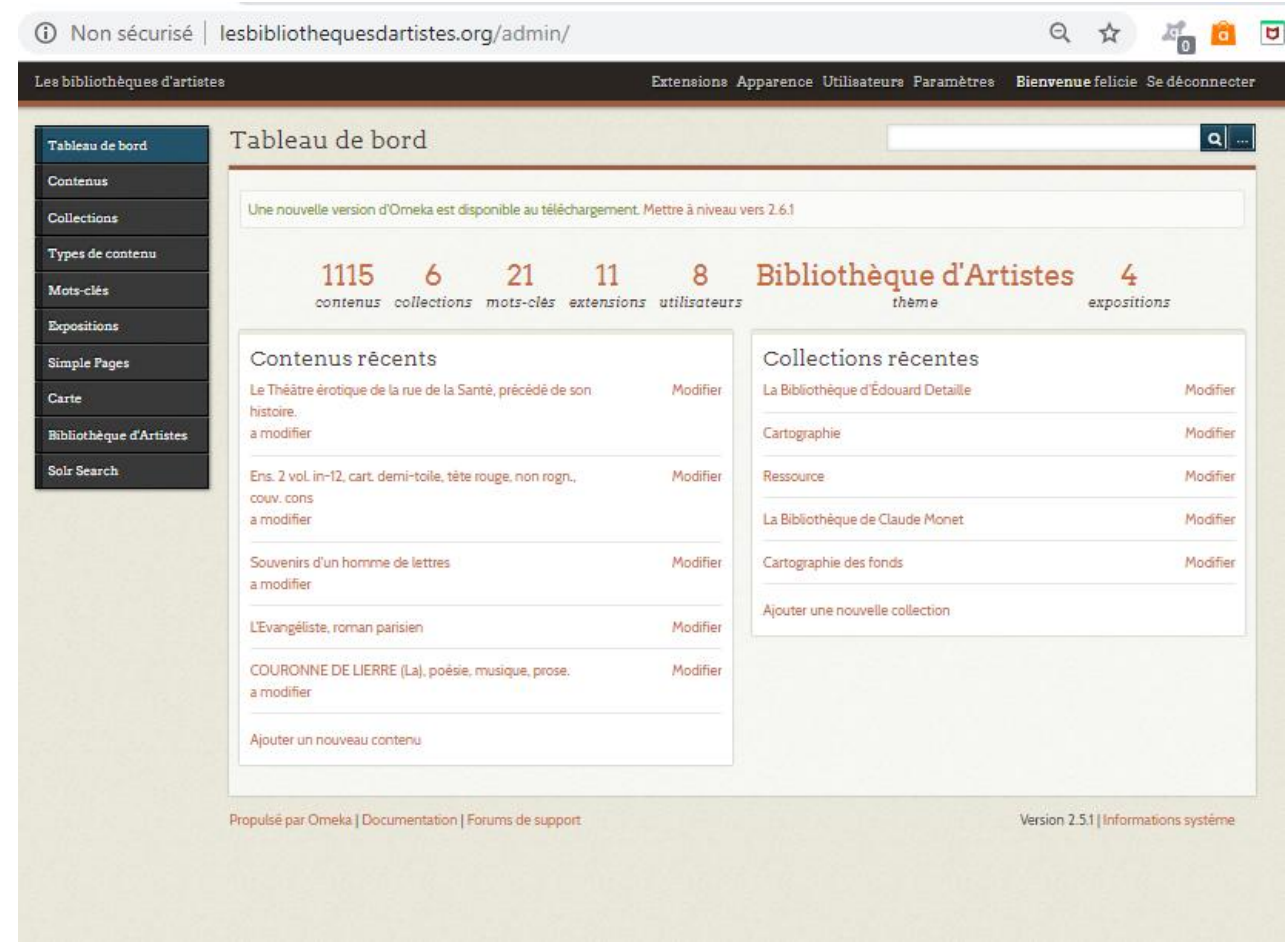

Figure 3. Dashboard of the omaka back office of www.lesbibliothequesdartistes.org

Apart from the question of content management, there is also the issue of data dissemination, since the central challenge is to make this valuable resource accessible. It is therefore necessary to design a user-friendly search function and consultation interface. For this purpose we must first ask ourselves, who will be our public? Do we target a very specialized research audience or a wider audience? The underlying question, which is particularly relevant in today's research world, is that of valorization. The tools and discourses must be adapted to the intended audiences. If the project is first designed for researchers, it can also interest a broader audience. That's why we chose to design two levels of search engines: a simple one using only keywords and an advanced one which, by refining the criteria, makes it possible to find very specific documents. In the case of artist libraries, cross-questioning will be particularly interesting, because we want to know not only if Monet had a copy of Don Quixote or La Fontaine's Fables ${ }^{25}$, but also in which edition. Plus we want to leaf through the digital copy in question, and furthermore, we want to know if other artists of his generation also owned those books and if they were the same editions illustrated by Gustave Doré.

As the project is designed for research and not just sharing resources, we needed a website that could serve as a veritable research portal, i.e. where the community of researchers on artists' libraries can get to know each other and disseminate their studies either in academic format (scientific bibliography and papers) or a format for the broader public (virtual exhibitions). In addition to this and before integrating the entire catalog of a new library, we carry out the very important task of pointing geographically these resources. This takes the form of a map, initially elaborated as a simple plug-in and now fully developed on the online version of ARCGIS. On the website of the project, we integrated a viewer of this map which is clickable to access to ARCGIS site. Each artist library is figured on the map where it is kept. That's why there are sometimes several libraries on one point, for example at

\footnotetext{
${ }^{25} \mathrm{He}$ actually did have those books: Miguel de Cervantes, L'ingénieux Hidalgo Don Quichotte de la Manche. Trad. Louis Viardot et 370 compositions de Gustave Doré, Paris, 1869 ; Jean de La Fontaine, Fables. Avec les dessins de Gustave Doré, Paris, 1868.
} 
Bibliothèque Kandinsky - Centre Georges Pompidou in Paris. The libraries are classified by types (material founds, reconstituted, from inventory or sales catalogs). Thanks to the various tools (the plug-in) it offers, Omeka is a very adaptable CMS that can support these different goals. Alongside the database and its connected visualization tools, the project functions as an entire website.

) Non sécurisé | lesbibliothequesdartistes.org/cartographies-des-fonds
Cartographie des fonds

Sur cette carte interactive découvrez les lieux où consuiter des bibliothèques d'artistes.

Ces dernières ont ette classés en differentes catégories : les fonds conservés, les inventaires qui regroupent toute forme de liste d'ouvrages ayant appartenus a un artiste, les catalogues de ventes qui representent une source precieuse pour recontituer des fonds bien souvent trouve la trace dans des sources secondaires.

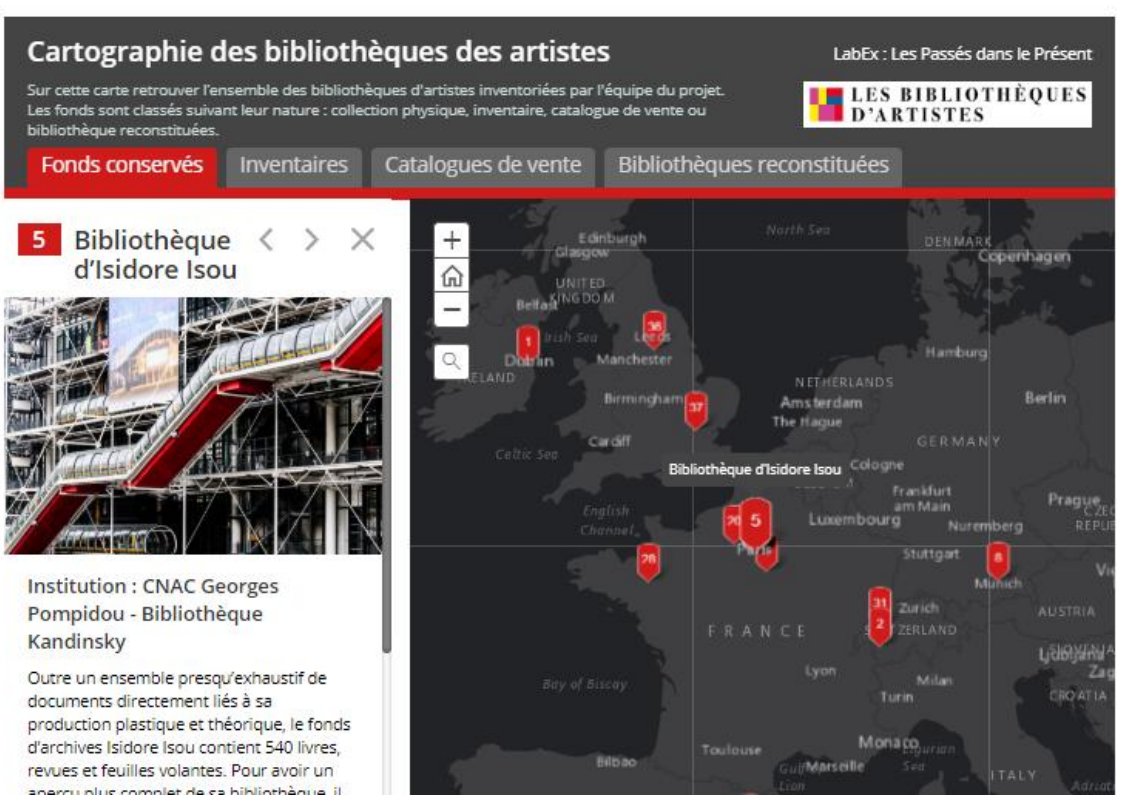

Figure 4. Map of artist libraries on www.lesbibliothequesdartistes.org

\section{THE PROJECT NOW}

The work on Monet's library is now finished. The catalog of the Giverny library was produced by Claudette Lindsey ${ }^{26}$ and Monet's foundation team upstream. It gave way to the publication of the anthology of texts [Le Men et all, 2013]. A second step has consisted of checking this list of works against those kept at the Bibliothèque nationale de France and already digitized on Gallica. If they are not, the aim is to include these books in its digitization process. This phase has required more time than expected. This is partly due to the nature of the works kept in Monet's library. A large part of these books are best-selling publications of the time, which were subsequently reprinted or reissues many times, sometimes in close succession. Because we want to know what the artist actually read and saw, we normally consider only the right edition. But it is also important that the user can at least read the text. That's why, when the right digital version doesn't exist, we give access to an approximated edition. The most important issue is to clarify each case: is the digital version exactly the same as the one the artist had, or an approximate version? The time needed to achieve this work is also due to technical reasons. Because of the accuracy we need in our bibliographical matching between

\footnotetext{
${ }^{26}$ See Paul Hayes Tucker et alii, Monet's Late Works, New York, Gagosian Gallery, 2010 (including "Monet's Library" by Claudette Lindsey).
} 
our primary resource and the digital version, it was not possible to know automatically if Monet's books were already digitized by Gallica. We had to check all 900 books manually ${ }^{27}$ !

After cleaning data and choosing digital tools, the project then entered the implementation phase. All of Monet's books are now available online. In addition to its obvious scientific intrigue, this first case study was used to test and validate the choices we made, to be able to apply them to other libraries and other artists, whether painters, sculptors, architects, etc. The choice of Monet offers many advantages: first the amounts of books. 900 are enough to test the digital tools on a large scale but not too much when you have to correct some bugs. Our knowledge of the subject was an asset too. Because if we built a general database in which every library can be catalog, each one is in fact specific. For that reason, Monet's library was not a good choice for the question of reading marks. Monet almost never annotated his books. If we have still taken in account this crucial aspect of a private library, we have never managed it in the full magnitude it can have.

\section{THE PROJECT IN THE FUTURE}

The shift from a monographic scale to a global scale will create the right conditions for developing analytical and critical thinking about artists' libraries, both considered as an entity in its own right and as a set of independent objects, themselves composed of pages sometimes annotated and illustrated. By comparing the libraries, the goal is no longer only to reveal the reader's portrait behind that of the artist, his interactions with the cultural sphere of his time and past, and a part of his creative process, but also the cultural environment of a time. To achieve this goal we are currently working on libraries of other impressionists. It is a longterm job because no other, except that of Monet, is materialy kept. In the mean-time, the choice of the next library to be included in the database is partly pragmatic. One of the next libraries is the one of the painter Edouard Detaille (1848-1912). His library is known thanks to a sales catalog, kept in the National Labray of France ${ }^{28}$. If his aesthetic is far from that of the impressionists, our first research shows that some readings are common. This first comparison proves that through the study of libraries we will certainly discover the importance of a shared culture well beyond the traditional division established by art history. It is the same logic that drives us to take an interest in the library of the sculptor Antoine Bourdelle (1861-1929). We will also open a new contemporary field with the libraries of Hans Hartung (1904-1989) and his also painter wife Anna-Eva Bergman (1909-1987) and the sculptors Alberto Giacometti (1901-1966). At the end of 2019, those libraries will be included in the database and disclosed on the website. We also continue to fuel the map.

The developments envisaged are not only about resources but also technique. Today we have two options to integrate a new library: either book by book by the Dublin Core form in omeka back office or massively via a CSV file. This second option is much faster. When we work with a partner institution, we firstly fill their database, then we extracts the data in excel format, works on the spreadsheet to adapt it to the project standards and finally integrate the data to our database. The next step is to use the interoperability to retrieve the data automatically, when the inventory is already done. Omeka-S, the newest version of the software could be effective because it supports web semantic languages. The other major

\footnotetext{
${ }^{27}$ This work was conducted, with the oversight of the author and the corresponding author, by two students from Paris Nanterre University, Hortense Rolland and Rivka Susini.

${ }^{28}$ Bibliothèque de feu Édouard Detaille, membre de l'Institut, président de la Société des Artistes français, J. Meynial, [1913]. Vente, 23-26 avril 1913, Paris (Hôtel Drouot). Com. Pris. : Ch. Dubourg, Lair-Dubreuil].
} 
works in progress is on the illustrations contained in the books. Originally, one of the project goals was to discover a lesser known part of the artists' musée imaginaire built on those illustrations. We wanted to identify all of these illustrations. There are far too many of them to do manually. We thought that it would be quite easy by working on the digital versions. But when Gallica scans the books, they don't differentiate between text and picture. That's why it is impossible at this time to process automatically. The question of automatic recognition is a topical interest at the BnF so that we can hope that this will be developed soon. It may also be interesting to set up customization, i.e. the user can organize and structure the data in his own way. This would allow them to create their own thematic library, take notes or directly annotate the works, and then share the results.

Although we will surely encounter other technical challenges as we progress, we are confident that the goals of data expansion to enable a comparative approach will leaving lasting impacts on the way art history research is conducted.

\section{References}

Levaillant F., Bouiller J.R. and Gamboni D. (eds.), Les bibliothèques d'artistes, Paris, PUPS, 2010.

Le Men S., de Maupeou F., Maingon C., La bibliohèque de Monet, Paris, Citadelles et Mazenod, 2013.

Hayes Tucker Paul et alii, Monet's Late Works, New York, Gagosian Gallery, 2010 (including "Monet's Library" by Claudette Lindsey).

Le Men S., 'Artists Libraries: A Resource for Art History, Perspective : actualité en histoire de l'art, 2016-2, p.111-132. https://journals.openedition.org/perspective/6872

Faizand de Maupeou F., «Les bibliothèques d'artistes au prisme des humanités numériques : la bibliothèque de Monet », Perspective : actualité en histoire de l'art, 2016-2, p.175-181. https://journals.openedition.org/perspective/6939 